\title{
PUTTING COMMUNITY EQUITY IN COMMUNITY DEVELOPMENT: RESIDENT EQUITY PARTICIPATION IN URBAN REDEVELOPMENT
}

\author{
By Barbara Bezdek ${ }^{1}$
}

Property is more accurately described as being inextricably part of a network of relationships that is neither limited to, nor usefully defined by, the property boundaries with which the legal system is accustomed to dealing. ${ }^{2}$

Property is inextricably bound up in a network of economic and social relationships.

Regulating the negative externalities of land use that traverse legal boundaries and impose social costs on neighbors lies at the heart of much of our land use law. ${ }^{3}$ Cities are comprised of neighborhoods, within which communities sharing a geographic space over time, establish that "small-scale, everyday public life" and learn to manage themselves through working relationships and voluntary association. Jane Jacobs called this the "irreplaceable social capital" that gave cities their life, as she railed against modern urban planning for destroying that cooperative condition and thus the trust and social control necessary to viable neighborhoods within big cities. ${ }^{4}$

The loss of communities is the predictable result of local government policies to deploy land use powers and sink public subsidy into for-profit redevelopments that disperse low-wealth residents, re-title the land, and reallocate urban blocks to remake inner city neighborhoods. In

\footnotetext{
${ }^{1}$ Professor of Law, University of Maryland School of Law. I am grateful for the comments of the participants at the Workshop on Affordable Housing and Public/Private Partnerships, October 19-20, 2007.

2 Joseph L. Sax, Takings, Private Property and Public Rights, 81 YALE L. J. 149, 152 (1971).

${ }^{3}$ Euclid v. Ambler Realty Co., 272 U.S. 365, 391 (1926) (upholding early zoning code in urban areas for the purpose of separating "noxious" and incompatible uses of neighboring properties); Joseph Sax argued thirty-five years ago that because certain uses of property could have adverse effects on wetlands, forests, streams, and similar natural features, members of the public seeking to preserve such resources on privately owned land sought to vindicate a public interest in common resources which was rooted in part in the "maintenance of those resources found necessary to sustain the well being of the community." Sax, supra n. 2, at 157-59. The environmental land-use movement that followed is recounted in Patricia E. Salkin, From Euclid to Growing Smart: The Transformation of the American Local Land Use Ethic into Local Land Use and Environmental Controls, 20 PACE ENVTL. L. REV. 109, 113 (2002).

${ }^{4}$ JANE JACOBS, THE DEATH AND LifE OF GREAT AMERICAN CitIES 146-183 (1961).
} 
effect these redevelopment practices specially tax existing communities in the path of development, sweeping aside their tangible and intangible capital and connections, while they cater generously to wealthier in-movers. The special concern of this paper is to recalibrate the benefits of private-public partnerships to remake inner city neighborhoods, by braking the rate at which urban land is being reclaimed from low-wealth residents by local governments, whether as blight clearance or for economic revitalization post-Kelo. ${ }^{5}$ Public oversight requirements have not kept pace with the dispossession, yet the costs that these development decisions impose on the social fabric of communities rend the shared networks necessary to residents' abilities to meet basic social needs, like raising children or earning a living. ${ }^{6}$ Jacobs warned that once the web of this "social capital" is destroyed, accumulating new social capital in the re-made place is a slow and chancy proposition. ${ }^{7}$

Today many critics seek to limit the authority of government to use eminent domain for urban redevelopment, to shrink the opportunity for monied interests to leverage government power for their own projects. Alternatively, others argue for improving the procedures required before the exercise of eminent domain, or for changing the meaning of "just compensation." 8

\footnotetext{
5 Kelo v. City of New London, 545 U.S. 469 (2005). Suzette Kelo's pro bono counsel, The Institute for Justice, maintains detailed accounts of municipal exercises of eminent domain for private, economic development-related land assembly, at Castle Coalition, http://castlecoalition.org. The Institute for Justice reports that following Kelo, the use of eminent domain for private development disproporationately affects residents who are ethnic or racial minorities, live at or below federal the poverty line, and have completed significantly less education, compared to people in the surrounding communities. DiCK M. CARPENTER \& JOHN K. ROSS, VictimizInG THE VulNERABLE, THE DEMOGRAPHICS OF EMINENT DOMAIN ABUSE 2 (June 2007) available at http://www.ij.org/images/pdf_folder/other_pubs/Victimizing_the_Vulnerable.pdf.

${ }^{6}$ Mindy Thompson Fullilove, Root Shock: How Tearing Up City Neighborhoods Hurts America, AND What We CAN Do ABout It (One World/Ballantine 2004) [hereinafter FulliLOVE, RoOt SHOCK].

${ }^{7}$ Jacobs, supra note 4, at 180 .

${ }^{8}$ James J. Kelly, Jr., Taming Eminent Domain, SHELTERFORCE, March 22, 2008, http://ssrn.com/abstract= 1271223; J. Peter Byrne, Condemnation of Low Income Residential Communities under the Takings Clause, 23 UCLA J. ENVTL. L. \& POL'Y 131 (2005).
} 
This essay explores the creation of community equity shareholding in public/private redevelopment projects. Community Equity Shares (CES) embody three principles. First Community equity shareholding recognizes limited rights in an existing community, akin to land ownership, as the basis for both participation in the decision-making about the character of the redevelopment, and profit participation in the redevelopment projects that displace long-term residents. ${ }^{9}$ Second, by instantiating social and geographic community as ownership in the calculus of land-use, it is possible for residents in the district of a proposed redevelopment to parlay those shares for two purposes: for participation in the decision-making about proposed redevelopment, and for participation in the profits from the displacing redevelopment project. A third principle is to add a player, the special-purpose Community Equity Corporation comprised of all the community equity shareholders and wielding their limited powers in common, to the redevelopment deal-making that, unchecked, would impose undue burdens including displacement upon the long-term residents of the targeted district. Community Equity Shareholding can be effectuated by changes in local governments' redevelopment and procurement procedures, which can assist to change the governmental calculus when it uses or threatens to use its land use powers to displace low-income communities as it re-engineers urban environs in concert with private developers.

\section{STATUS QUO DEVELOPMENT BY DEAL-MAKING}

The principal legal form for remaking city neighborhoods is the public/private partnership (“PPP”) by which local government agencies trade essential infrastructure at low or no cost in exchange for a profit-sharing stake or other anticipated return on the city's

\footnotetext{
${ }^{9}$ See Barbara L. Bezdek, To Attain "The Just Rewards of So Much Struggle": Local-Resident Equity Participation In Urban Revitalization, 36 HOFSTRA L. REV. 37 (2006) [hereinafter, Local-Resident Equity Participation].
} 
investment. ${ }^{10}$ Cities have been deal making in this way since the 1970 s, $^{11}$ yet the scale, pace, complexity and bilateral character of today's municipal reliance upon $\operatorname{PPPs}^{12}$ evades the ability of the locality's people to assure that their government is acting for the general welfare, rather than for select other segments of the populace. A more particular application of this principle can be stated in the context of intensive redevelopment of deteriorated neighborhoods: local government should not callously jettison urban residents and scatter them for the gain of private developers and wealthier in-movers, without enabling the resident community members also to gain from the renewal of their neighborhood. In a well-functioning democracy, government's role is to responsibly assess the social welfare costs and benefits of its powers, without illegitimate favoritism or unjustifiable disparate impacts. Particularly in land use law, the central problem is to regulate the imposition of social costs onto others arising from a specific use of

${ }^{10}$ About thirty states have legislation authorizing local governments to negotiate disposition and development agreements, express contracts with private partners.

The arrangement can be successful for municipalities and their private partners. "The bundle of sticks associated with land ownership has been deliberately broken apart and replaced with a pattern of contractual responsibilities that, given the nature of the deal, allocates to the respective public and private parties the specific elements of assembly, clearance, construction, maintenance, and control they are best equipped to perform." Marc B. Mihaly, Public Private Redevelopment Partnerships and the Supreme Court, 7 VT. J. OF ENVTL. LAW 41 (2006).

11 City officials became dealmakers during the 1970 s in order to complete projects begun under federal urban policies, and used their funds to adapt the lessons learned following the withdrawal of federal funds in the 1980surban fiscal distress's peak. EdWARD J. BlaKely, PlanNING LOCAl ECONOMIC DEVElOPMENT: ThEORY AND PRACTICE 153-54 (Sage Publications, Inc. 2d ed. 1994). The avowed purpose is typically to enhance the city's tax base, see for example Philadelphia's Society Hill; Baltimore developer Bill Stuever praises the "public-private partnerships" in an effort to build the city's tax base. Andrew Cannarsa, Study criticizes city's redevelopment, says practices have created "two cities", The Examiner, June 24, 2008, found at http://www.examiner.com/printa$1455745 \sim$ Study criticizes city\%E2\%80\%99s redevelopment, says practices have created \%E2\%80\%98two citi es\%E2\%80\%99.html, accessed Nov. $7^{\text {th }}, 2008$.

${ }^{12}$ Lynne Sagalyn recently observed that we are now in a third generation of PPP types: in the 1970s, municipalities and private developers learned by doing; in the 1980s, large specialized development companies emerged with comparative national expertise, and several cities have established special purpose corporations, project-specific entities. The third wave PPPs are commonly initiated by developers seeking public-sector involvement, which some have called 'private-public' development to signal the enthusiasm for private investment in urban neighborhoods among equity investment firms. These projects pose new challenges, since government does not own the development sites in many developer-initiated projects, giving public officials less bargaining power than when they hold legal title. Lynne B. Sagalyn, Public Private Development: Lessons from History, Research and Practice, $73 \mathrm{~J}$. OF THE AMERICAN PlanNing ASSOCIATION 7, 17 (2007). 
land. The law governing urban redevelopment is overdue for a corrective that will force the internalization of its true social costs.

The private contract model of development agreements and public/private partnerships renders invisible the inequitable allocation of the benefits and burdens of the deals that redistribute urban territories. The disfavored occupants of areas targeted for redevelopment garner no demonstrable share in the supposed gain to the general welfare which is the doctrinal justification for the city's exercise of governmental powers to condemn and re-title the residents' neighborhoods. In reality of course, courts referee very few of these clashes between the interests of low-income residents for affordable housing and the social capital accrued in their neighborhood, and the interests of higher-earning and spending denizens that cities aim to attract to the newly developed urban territories. Low-wealth communities are replaced by new upscale housing and shops and a brighter urban image. The displaced bear burdens which their compatriots do not: the destruction of their long-time neighborhoods and the social capital they have built up there. All gone in a Diaspora: the old neighborhood destroyed. ${ }^{13}$

Local governments participating in the urban real estate market in this way are often frank about their purpose to engineer new urban territories and repopulate them with the wealthier classes. ${ }^{14}$ In the U.S. this urban social engineering is sometimes characterized as a

\footnotetext{
13 Forced displacement by development is a global problem of enormous dimensions and dire consequences for millions. Accordingly, in international development, numerous scholars track that displacement to distill knowledge of displacement's social costs for the displacees into patterns of predictable, cumulative dimensions of impoverishment, in order to devise successful resettlement practices for people involuntarily displaced by development. See, e.g., Michael M. Cernea, Impoverishment Risks, Risk Management, and Reconstruction: A Model for Population Displacement and Resettlement, http://www.un.org/esa/sustdev/sdissues/energy/op/hydro_cernea_population_resettlement_background paper.pdf (last visited October 20, 2008).

${ }^{14}$ Roberto G. Quercia \& George C. Galster, Threshold Effects and the Expected Benefits of Attracting MiddleIncome Households to the Central City, 8 HousING POL'Y DEBATE 409, 412-413 (1997) (anticipating fiscal and social benefits of revitalization). Robin Paul Malloy, The Political Economy Of Co-Financing America's Urban
} 
modern version of the pioneering that peopled the American plains with striving Europeans. ${ }^{15}$

The public policy to restructure the territories of the central city unfairly allocates the costs of revitalization to the current residents and distributes the benefits to others. Increasingly, it is the developer, not the government, who initiates the redevelopment project and dictates the deal. ${ }^{16}$ This is the antithesis of governance for the general welfare. This is not new, but its familiarity should engender sharper scrutiny, and new thinking to correct for its inequities.

\section{TAKING THE COMMUNITY, INFLICTING "NEW POVERTY"}

Targeted redevelopment projects in central city neighborhoods cause more harm to lowwealth urban neighborhoods than the physical insertion of unaffordable amenities and the physical displacement of longstanding residents and businesses. Investigations into displacement reveal risks that deeply threaten displaced households' chances of relocating "well": these include joblessness, homelessness, marginalization, loss of commonly enjoyed

Renaissance, 40 VAND. L. REV. 67, 101-104 (1987) (analyzing complex cross-subsidy and co-financing model of urban redevelopment and concluding that key constituents most likely to benefit are "politicians and business people... real estate professionals - lawyers, brokers and bankers...local union workers such as construction workers who find work at the new projects, and local workers employed to clean and service the new buildings."). See also Audrey G. McFarlane, The New Inner City: Class Transformation, Concentrated Affluence And The Obligations Of The Police Power, 8 U. PA. J. Const. L. 1, 6-12 (2006) (citing numerous cities' development policies to encourage upper-middle class residential occupancy).

15 See, for example, McFarlane, supra note 14, at 5 (documenting the territorial reclamation of city centers worldwide for the affluent).

Urban places that were once racialized as Black and classified as poor, dangerous, and off-limits to anyone of affluence and with choices, have taken on new meaning today. These places are now suppliers of housing that is relatively cheap, centrally located, and often architecturally rich. They are open territories for investment speculators, redevelopment agencies, and affluent professionals who reject the suburban form of living, but demand, and can easily pay for, luxury residential, commercial retail, entertainment, and other intangible spatial amenities.

The nineteenth century federal statutory regime to expand westward and push out American Indians, An Act to Secure Homesteads to Actual Settlers on the Public Domain, 12 STAT. 392 (1862) (43 USC 161, was repealed in 1976). See generally Mark E. Brandon, Home on the Range: Family and Constitutionalism in American Continental Settlement, 52 EMORY L. J. 645, 671-677 (2003) (discussing political and economic understandings of "settlers" and "speculators" at that time).

16 See, e.g., City of Norwood v. Horney, 830 N.E.2d 381, 383-85 (Ohio Ct. App. 2005); Gideon Kanner, The Public Use Clause: Constitutional Mandate or "Hortatory Fluff"?, 33 PEPP. L. REV. 335, 336 (2006) (arguing that cities which stand to gain financially from joint development deals have an inherent conflict of interest in the exercise of the police power for the general welfare). 
spaces and social resources, increased health risks, social disarticulation, the disruption of formal educational activities, and impairments of civil rights in voting and fair housing rights. Failure to recognize and avoid these risks may generate "new poverty," as opposed to the "old poverty" that people suffered before displacement. ${ }^{17}$

\section{A. Exclusionary Displacement}

Compulsory displacements that occur for development reasons raise major questions of social justice because they inequitably distribute the losses and benefits of the redevelopment. In the paradigmatic context for the exercise of eminent domain power for true public uses, forced displacement results from the need to build infrastructure -- highways, hospitals, schools, and airports. Such programs improve many people's lives, deliver indisputably important services, and proffer employment. Nonetheless, the interests of residents facing displacement differ in kind and quality from the general public's - possessory and economic - many of which do not figure in the official costs of land assembly despite their complete extinguishment. While local governments claim to advance the general welfare as they funnel public resources into the redesign of urban spaces, it is hard to avoid the unvarnished truth that municipalities are terminating the residency of some in order to construct shiny, new, private residences and shops for affluent in-movers. This presents us with ineluctable issues of social justice and equity. Outside the condemnation regime, it is low-income tenants who bear the greatest burden as cities court an increased tax base through gentrification.

\section{B. Displacement by Destruction of Affordable Housing}

\footnotetext{
17 See Theodore E. Downing, Avoiding New Poverty: Mining Induced Displacement And Resettlement, Mining, Minerals and Sustainable Development (MMSD), International Institute for Environment and Development, April 2002, http://www.ted-downing.com/Publications/AvoidingNewPovMMSD.pdf.
} 
Cities' public/private redevelopment projects continue to use eminent domain powers to displace low-income households and raze their homes, but not to build more affordable housing. ${ }^{18}$ This effect was achieved on a grand scale in the Urban Renewal Era of the 1950s$1970 \mathrm{~s},{ }^{19}$ and in the successive forms of redevelopment since then ${ }^{20}$ as local governments have actively courted gentrification in inter-jurisdictional competitions for tax base.

Animating the legislative responsiveness to condo conversion was the powerful appeal of the security of 'home.' The specter of being forced from one's home is one of the paradigms of autocratic government (as well as ruthless creditors). Protection against such uprooting by government inheres in our concept of liberty, and has always been protected to some degree by our Constitution, for example in the Fourth Amendment as well as in the Takings Clause.

The contemporary crisis in housing affordability, which plagues millions of Americans caught in the crosshairs of disappearing low-cost housing, rising rents, and flat wages, raises the further fear among tenants of repeated relocation. Involuntary relocation discourages displaced persons from the exercise of a key organizational interest necessary in a democratic state. ${ }^{21}$

\footnotetext{
${ }^{18}$ Matthew J. Parlow, Unintended Consequences: Eminent Domain and Affordable Housing, 46 SanTA Clara L. REV. 841, 856-57 (2006) ("By taking such affordable housing units off the market by their exercise of eminent domain power, cities reduce the available housing stock for low-income residents as such units are usually replaced by new high-end commercial, residential, and mixed-use projects.").

${ }^{19}$ Colin Gordon, Blighting the Way: Urban Renewal, Economic Development, and the Elusive Definition of Blight, 31 FordHAM URB. L.J. 305, 311-12 (2004); Wendell E. Pritchett, The "Public Menace" of Blight: Urban Renewal and the Private Uses of Eminent Domain, 21 YALE L. \& POL'Y REV. 1, 49 (2003); Chester W. Hartman, Relocation: Illusory Promises and No Relief, 57 VA. L. REV. 745 (1971) (describing extensive uncompensated losses suffered by victims of urban renewal condemnations).

${ }^{20}$ George Lefcoe, Redevelopment Takings after Kelo: What's Blight Got to Do with It?, 17 S. CAL. Rev. L. \& Soc. Just. 803, 815 (2008); Lynn E. Blais, Urban Revitalization in the Post-Kelo Era, 34 FORDHAM URB. L.J. 657, 674 (2007) (noting that, of the 34 states that enacted post-Kelo limitations on their eminent domain powers, two thirds of these retained exceptions for areas that could be shown to be blighted).

${ }^{21}$ John Ely, DEMOCRACY AND DistruST 86-88 (Harvard University Press 1980); Frank Michelman, Property as a Constitutional Right, 38 WASH \& LEE L REV. 1097, 1112 (1981) (articulating the view that rights, including property rights, under a political constitution such as that of the U.S., are first to be regarded as political rights); Lawrence H. Tribe, Forward: Toward a Model of Roles in the Due Process of Life and Law, 87 HARV. L. REV. 1, 9 (1973) (rights between associational rights and rights of personhood).
} 
Even before the current foreclosure crisis, which has caused a substantial number of renters as well as homeowners to lose their homes, the number of households experiencing housing problems was increasing. From 2000 to 2006, the number of low-income renter households whose housing costs exceed 50 percent of their income (a group the Department of Housing and Urban Development categorizes as having "severe housing cost burdens") increased by 2 million, or 34 percent. More than 12 million low-income households receive no federal housing assistance and face housing problems that public housing (or other housing assistance) would alleviate, if there were a sufficient stock of assisted housing. ${ }^{22}$

Studies of urban renewal reveal that the typical residents displaced by urban renewal paid $20 \%$ more rent after being relocated $;^{23}$ from one-fourth to one-half of displaced families lived in substandard housing despite a substantial rent increase. ${ }^{24}$ In 1970 Congress enacted the Uniform Relocation Act (URA) to compel federal agencies, as well as state and local agencies receiving federal funds, to provide relocation assistance to "displaced persons," including payments to secure "comparable replacement housing." The most extensive study conducted since the URA was enacted is U.S. Department of Transportation Relocation Retrospective Study in 1995. Nearly $90 \%$ of the homeowners surveyed indicated that they were "able to significantly upgrade"

\footnotetext{
${ }^{22}$ Barbara SARD \& Will Fischer, Preserving SAFe, High Quality Public Housing Should be a Priority of Federal Housing Policy 5 (Center on Budget and Policy Priorities September 18, 2008). The nation retains 1.2 million public housing units, in 14,000 projects spread throughout 3,500 communities. These house 2.3 million Americans who are among the poorest and most vulnerable, due chiefly to age and disability. Two-thirds of the households include an elderly person; and $41 \%$ include children. $I d$. at 3 . Most public housing residents are extremely poor; the typical (or median) household in public housing had annual income of just $\$ 8,788$ in 2006 . Id. at 4. Seventy-three percent of the households living in public housing have incomes of 30 percent or less of the area median income for their household size. Id. at 5.

A family must be "low-income" - meaning that its income may not exceed 80 percent of the local median income - in order to move into public housing. At least 40 percent of the new families an agency admits each year must be "extremely low income," with incomes at or below 30 percent of the local median. Generally, agencies exceed this 40 percent requirement by a wide margin. Most tenants are required to pay 30 percent of their income (after certain deductions are taken out) for rent and utilities. $I d$.

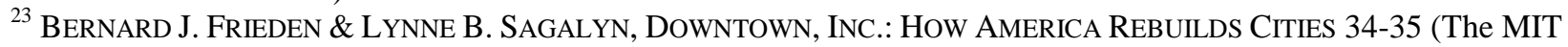
Press 1997).

${ }^{24}$ Chester W. Hartman, Relocation: Illusory Promises and No Relief, 57 VA. L. REV. 745, 781-817 (1971).
} 
their housing, but that over 50\% of those surveyed were no longer living in their replacement housing a year after receiving the payment. ${ }^{25}$ As reported recently by the United States General Accounting Office,

When private property is taken by eminent domain, hardship often follows. Neighborhoods may be disassembled, businesses may be forced to close. At an absolute minimum, individuals and businesses may be uprooted against their will. The "just compensation" mandated by the Fifth Amendment often does not and cannot provide adequate redress. For example, a tenant renting a house or apartment from month to month would most likely get nothing except an eviction notice. ${ }^{26}$

\section{Gentrification for Some}

Disputes about whether gentrification causes displacement, and if so, whether that is a good thing for the poor among the public, have been at the heart of heated analytic and political debates over urban change for the last forty years. ${ }^{27}$ There can be no serious disagreement that the U.S. has seen 20 years of intense gentrification and sweeping public policy changes that impact the shape of our cities. These operate in contemporary housing market dynamics at the national, regional and city levels, and can be expected to create a variety of displacement pressures, intersecting in locally contingent ways on neighborhoods occupying desired redevelopment locales.

Residents may be displaced directly as a result of housing demolition, owners' conversion of rental units to condominiums, increased housing costs in the form of rent or taxes,

\footnotetext{
${ }^{25}$ Fed. Highway Admin., U.S. DeP'T OF TRANSP., Relocation Retrospective StUdy 2 (1996).

${ }^{26}$ U.S. GAO, Relocation Assistance, IV PRINCIPLES OF FEDERAL APPROPRIATIONS LAW, 16 GAO RB pt C, s. 1 (2d. ed. 2001). Whereas payments made to "displaced persons" under the URA are not to be considered as income for purposes of federal income taxation or social security, they are deemed income for low-income housing assistance. Id. at 3 (citing 42 USC $\$ 4636$ ).

${ }^{27}$ See Kathe Newman \& Elvin K. Wyly, The Right to Stay Put, Revisited: Gentrification and Resistance to Displacement in New York City, 43 URB. STUDIES 23-57 (2006) (reviewing that literature, and presenting quantitative and qualitative analysis; concluding that while not all low-income residents are displaced by gentrification, because of New York City's "historically specific web of housing supports that developed ... from the 1920 s to the 1970 s." Id. at 51-52.
} 
landlord pressure, and eviction. Residents who manage to avoid these direct displacement pressures may nonetheless be displaced by rising housing expenses associated with gentrification. As affordable housing becomes scarce in gentrifying areas, neighborhoods become too pricey, requiring lower-income residents to search elsewhere for housing. ${ }^{28}$

Where earlier research accepted displacement as a part of the gentrification process, some recent studies raised doubt, finding that disadvantaged renters in New York City were somewhat less likely to move out of gentrifying neighborhoods than out of non-gentrified neighborhoods. ${ }^{29}$ Even so, this evidence, while new and useful, fails to reach far enough, for example to address the effects in conditions of rapidly gentrifying hot neighborhoods accelerate rent hikes that prices out even those lower-income residents who managed to remain during initial economic transition. ${ }^{30}$

The restructuring of urban space as cities experience economic and policy change impacts the ability of low-income residents to stay put. This narrow new evidence suggesting displacement may not always be dramatic, can be overused to dismiss concerns about the exclusionary effect of contemporary market-oriented urban strategies, featuring homeownership, mixed-income and social-dispersal strategies, and affluent-attractant downtown destinations, which have been widely embraced as curatives for the disinvested inner city. ${ }^{31}$

\footnotetext{
${ }^{28}$ Interim housing strategies for some include doubling or tripling up with family and friends; become homeless or move to city shelters; or move out of the city. Newman \& Wyly, supra note 27 at $45-46$ (reporting study results in Central Harlem, Lower Park Slope).

${ }^{29}$ L. Freeman \& F. Braconi, Displacement or Succession? Residential Mobility in Gentrifying Neighborhoods, 40 Urb. AfF. 463 (2004); L. Freeman \& F. Braconi, Gentrification and Displacement, 8 The Urban Prospect 1 (2002); J. Vigdor, Does Gentrification Harm the Poor?, 2002 BroOKINGS-WHARTON PAPERS ON URBAN AFFAIRS 134. See also Andres Duany, Three Cheers for Gentrification, AMERICAN ENTERPRISE MAGAZINE, April/May 2001, at 36-39; J. Peter Byrne, Two Cheers for Gentrification, 46 How. L. J. 405 (2003).

${ }^{30}$ Newman \& Wyly, supra note 27.

${ }^{31} I d$. at 25 .
} 


\section{Taking Social Capital}

Invasive redevelopment projects destroy vital social and cultural ties crucial to residents' ability to meet their basic social and economic needs. ${ }^{32}$ Displacement specialists working in international development call this "the resettlement effect," defined as the loss of physical and non-physical assets, including homes, communities, land, income-earning assets and sources, cultural sites, social structures, networks and ties, cultural identity and mutual help mechanisms. ${ }^{33}$ In the U.S., numerous studies document the significant economic and social welfare gains enjoyed by communities with strong social networks. ${ }^{34}$ William Julius Wilson has described the social organization needed to realize and maintain common neighborhood goals, and has argued that communities unable to sustain the social networks that enable collective action, are made vulnerable to a range of urban problems, preventing the types of collaboration essential to community-building. ${ }^{35}$

Scholarly investigations of social capital feature its collective dimensions, and identify the

\footnotetext{
${ }^{32}$ Bezdek, Local-Resident Equity Participation, supra note 9, at 80-83; Fullilove, Roот SHOck, supra note 6. Sheila Foster documents and discusses the concentration of hazardous land uses in certain neighborhoods that impair physical health and entrench discriminatory land use patterns that fragment urban space by race and class, in Sheila Foster, Justice From the Ground Up: Distributive Inequities, Grassroots Resistance, and The Transformative Politics of the Environmental Justice Movement, 86 CAL. L. REV. 775, 779-807 (1998).

${ }^{33}$ Cernea, supra note 14 , at 14 . Dolores Koenig, Toward Local DeVelopment Mitigating Impoverishment in Development-Induced Displacement and Resettlement, Research PRogramme on DevelopmentInDUCED DisPlaCEMENT AND SETTLEMENT (Refugee Studies Centre, Oxford University 2003) (reviewing the literature of more than thirty years' study of the impoverishment problem, critiquing the field's dominant model for mitigating risks and reconstruction developed by Cernea for the World Bank, as unduly dependent upon the state planning function, and recommending the democratization of planning by employing participation rather than by involving people in a project whose lines have already been dictated by higher levels), available at http://www.rsc.ox.ac.uk/PDFs/rrtoward local01.pdf.

34 For an extended review of the history, conceptualization and debates over social capital, see DAVID HALPERN, Social CAPITAL 1-19 (Polity 2005). Several studies are reviewed by Sheila Foster in The City as an Ecological Space: Social Capital and Urban Land Use, 82 Notre DAME L. REV. 527, 543-547 (2006). Commentators have long lamented the loss of social capital in American communities. More recently scholars have begun to offer methods by which to measure the presence and amount of social capital, and while quantitative assessment is complicated, a significant body of literature across many academic disciplines examines the empirical consequences of social capital and demonstrates an array of effects. $I d$.

${ }^{35}$ William Julius Wilson, When Work DisAPPEARs: THE WORLD OF THE NEW URban PoOR (Vintage 1997).
} 
forms of social capital within viable communities. ${ }^{36}$ Social capital is what persons draw on when they enlist the aid of others to solve problems, seize opportunities, or accomplish objectives - or seek just to cope. ${ }^{37}$ Social capital is formed by informal networks of people (family, friends, neighbors) who can collaborate to address shared problems and gain access to city political power. ${ }^{38}$ One form, coping capital, is especially important for people who are chronically poor because it takes the place of services that money otherwise would buy. ${ }^{39}$ Two other forms include social support - which may come in myriad forms such as help with a flat tire, a ride, a small loan - and social leverage that helps one get ahead or improve one's opportunities, as through access to job information or scholarship recommendation. ${ }^{40}$

The legal framework offered by property law recognizes numerous rights of persons residing in the path of municipality-assisted redevelopment, which currently are destroyed, without acknowledgement or compensation, in the exercise of urban redevelopment powers. ${ }^{41}$ Important community interests of persons and communities are similarly destroyed. Lee Ann Fennell has argued recently that spatial association should be treated as a distinct property entitlement, at least where patterns of exclusion combine to produce persistent spatial concentrations of poverty in urban areas, because of its character as a common resource that is vulnerable to problems of collective action. ${ }^{42}$

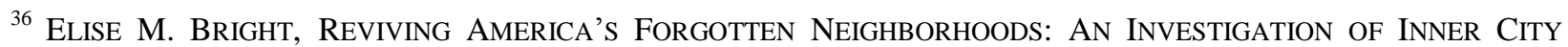
REVITALIZATION EFFORTS 13 (Garland 2000).

${ }^{37}$ Id.; Xavier de Souza Briggs, Brown Kids in White Suburbs: Housing Mobility and the Many Faces of Social Capital, 9 HOUSING POL'Y DEBATE 177, 178 (1999).

38 Bright, supra note 36 at 8.

${ }^{39} \mathrm{Id}$.

${ }^{40} \mathrm{Id}$.

${ }^{41}$ See Bezdek, supra note 9, at 70-73.

${ }^{42}$ Lee Anne Fennell, Properties of Concentration, 73 U. CHI. L. REV. 1227 (2006).
} 
Neighborhood is a necessity for urban living. ${ }^{43}$ Urban renewal and gentrification, which clear out the old residents of stable yet poor neighborhoods, deprive poor residents of a vital support structure. $^{44}$

In its physical aspect, a community provides benefits to persons that they otherwise could not enjoy alone: amenities such as schools, stores, transit, and other public goods or privately provided services are only available because of the sufficient demand in the area. ${ }^{45}$ Social interactions are another set of important benefits - friendships and interpersonal networks of all kinds that are possible because of physical proximity and common experiences of place and connection that endure over time. ${ }^{46}$ Particularly for people living at the lowest levels of income and materiale, the concern and support of neighbors is critical to physical survival, as well as to psychic well-being. "When this milieu is destroyed and its members scattered, it is irretrievably lost.",47

\footnotetext{
${ }^{43}$ See Peter L. Berger \& Richard John Neuhaus, Neighborhood, in To EMPOWER People: From State to Civil SOCIETY 165, 165-76 (Michael Novak ed., 2d ed. 1996); see also e.g., Jack L. Nasar \& David A. Julian, The Psychological Sense of Community in the Neighborhood, 61 J. AM. PLAN . ASSN 178, 181 (1995); see also David M. Chavis \& Abraham Wandersman, Sense of Community in the Urban Environment: A Catalysts for Participation and Community Development, 14 AM. J. COMMUNITY PSYCHOL. 55, 55-61 (1990); Thomas J. Glynn, Neighborhood and a Sense of Community, 14 J. COMMUNITY PSYCHOL. 341, 349, 351 (1986) (discussing the values of length of residency, knowing people by name, and ability to have community action such as electing caring officials); Thomas J. Glynn, Psychological Sense of Community: Measurement and Application. 34 HUM . REL; . 789, 790, 793 (1981); David W. McMillan \& David M. Chavis, Sense of Community: Definition and Theory, 14 J. COMMUNITY PsYCHOL. 6 (1986) (measuring neighborhood sense of community).

44. See William Michaelson, Residential Mobility \& Urban Policy: Some Sociological Considerations, in RESIDENTIAL MOBILITY AND PUBLIC POLICY 79, 83-85 (W.A. V. Clark \& Eric G. Moore eds., 1980); see also Stephanie Riger \& Paul J. Lavrakas, Community Ties: Patterns of Attachment and social Interaction in Urban Neighborhoods, 9 AM. J. COMMUNITY PSYCHOL. 55, 55-57 (1981). See also AMITAI ETZIONI, THE SPIRIT OF COMMUNITY; RIGHTS, RESPONSIBILITIES, AND THE COMMUNITARIAN AGENDA passim (1993); Oddvar Skjaeveland et al., A Multidimensional Measure of Neighboring, 24 AM. J. COMMUNITY PSYCHOL. 413, 422-25 (1996).

${ }^{45} I d$. at 113 . This concept can be viewed as the "joint defrayal of fixed costs in providing essential amenities." Id. at 116.

${ }^{46} I d$. at 114; see also Edward Glaeser, The Future of Urban Research: Nonmarket Interactions, 1 BROOKINGSWHARTON PAPERS ON URB. AFF. 101, 101-04 (2000), available at http://muse.jhu.edu/ demo/brookingswhartonpapersonurbanaffairs/v2000/2000.1 glaeser.pdf.

47 "The poor must often depend on a web of mutual support ... with each individual contributing to the others whatever ... special talents he might have. [Such] exchanges ... reinforce [each other], creating a milieu the value of which far exceeds what the physical reality might suggest." Denis J. Brion, The Meaning of the City: Urban Redevelopment and the Loss of Community, 25 IND. L. REV. 685, 702 (1992).. Personal recollections of such webs of mutual support are related by Dr. Fullilove in ROOT SHOCK, supra note 6.
} 


\section{COMMUNITY-INCLUSIVE CAPITAL FORMATION}

Community equity shareholding recognizes the meaningful claims of residents who will be displaced by changes in urban land use patterns, by allocating to each adult an equity stake in the wealth generated by such city-supported urban redevelopment. Absent a meaningful role for residents, local government in effect conveys their existing social place and relationships, at discount, in order to re-engineer urban environs for the mutual gain of private developers and the city. Community shareholding brokers the long-experience of community residence as a basis for participation in the decision-making about redevelopment, and profit participation as a form of material benefit from redevelopment projects that displace long-term residents. ${ }^{48}$

Conceptually, the collective action of those slated to be displaced by revitalization projects is a means to change the governmental calculus when it uses (or threatens to use) its land use powers to displace low-income communities. ${ }^{49}$ One form for such collective action is community legal control of the land use and redevelopment decisions accorded by the City of Boston to the Dudley Street Neighborhood Initiative - a model which is much admired but never replicated. Jim Kelly has recently proposed the creation of a federal right to "renew and remain" through amendment of the Uniform Relocation Act of $1970 .^{50}$ This essay proposes another tack, the creation of community equity shareholding in public/private redevelopment projects.

Community members ought not lose their substantial investments in their place, nor have

\footnotetext{
${ }^{48}$ Bezdek, Local-Resident Equity Participation, supra note 9.

${ }^{49}$ This practice and the recurring outcomes motif might well be altered by raising the cost to local officials of trading away low-income housing located in neighborhoods or localities eyed for redevelopment. Low-income residents would benefit from policies that would provide meaningful incentive to create substitute low-income housing in the same neighborhood, and configure new development so as to leave such housing in place.

50 James J. Kelly, Jr. Taming Eminent Domain, SHELTERFORCE, March 22, 2008, available at http://ssrn.com/abstract=1271223. The Uniform Relocation and Real Estate Acquisition Policies Act (URA) requires the governmental agency involved in any project using federal funds to provide relocation benefits to homeowners, tenants, businesses and nonprofits who are "displaced persons" as defined in the Act.
} 
their residency terminated by local government land use practices that transfer public resources into largely private redevelopment of residences for others, unless and until residents have approved the redevelopment. Such approval might be accompanied by an agreement to exchange their community residency interests for an equity stake in the benefits generated by the new development. Such an equity stake could take the form of an alienable right to comparable replacement housing in the new development, or to shares in the increased economic value justifying the public participation in the project and generated by it over time, or both.

This set of property interests can be recognized through reforms of the redevelopment planning requirements of state enabling statutes, to create Community Equity Shares held by residents of the properties whose area is targeted for redevelopment. The result is a process that invests residents with rights to consent to development beforehand, and to a share in the benefits of the deal in which the locality partnered. ${ }^{51}$

\section{A. Building Wealth: Models of Inclusive Capital Analysis}

Poor people and racial minorities have for generations gotten the disproportionate share of the burdens of land expropriation for urban redevelopment; and eminent domain doctrine is insufficient to reach their reality. "Property" forms a crucial nexus between the struggle for well-being, and the capacity to accumulate some predicate quantity of the material aspects that aid persons to be well, secure, and autonomous.

\section{Assets \& Opportunities for Enhanced Well-being}

51See generally Daphna Lewinsohn-Zamir, The Objectivity of Well-being and the Objectives of Property Law, 78 N.Y.U. L. REV. 1669 (2003) (arguing for an objective theory of well-being for legal theory and developing an objective approach to property law). Applying a new economic 'happiness' literature in the context of corporate governance, James McConvill has proposed that shareholder participation should be seen as an end in itself, rather than simply a means to a corporate-oriented end. James McConvill, Shareholder Empowerment as an End in Itself: a New Perspective on Allocation of Power in the Modern Corporation, VOL. 33 OHIO NORTHERN U. L. REV. 1013, 1015 (2007). Cf. Harry G. Hutchison and R. Sean Alley, The High Costs of Shareholder Participation, http://ssrn.com/abstract=1112885. 
The critical assets of poor households in our cities tend to be largely undocumented, and not readily parlayed into formal recognition in the legal processes that structure land transfer and land use decision-making. ${ }^{52}$ When Hernando de Soto, seeking to document the asset accumulation capacity of deeply impoverished people in developing nations, estimated their undocumented property holdings to exceed $\$ 9$ trillion, he also argued that the absence of legal recognition of their property presented a near-complete impediment to turning their assets into useful capital. $^{53}$

Significant movement toward this recognition is perhaps underway. Anti-poverty advocates and policymakers have embraced asset-building strategies, prompted by the influential work of Michael Sherraden and colleagues who since 1991 have argued that modern welfare policy fails in its singular emphasis on income rather than a recognition of assets as a measure of economic well-being. ${ }^{54}$ Assets, argues Sherraden, properly understood, encompass less tangible resources including human capital, cultural capital, political capital and social capital, ${ }^{55}$ as well as tangible money savings, real property, stocks and bonds. ${ }^{56}$ The meaningful assets in the lives of many working yet poor urban residents in the U.S. consist of items far removed from our

\footnotetext{
53 Hernando De Soto, The Mystery of Capital: Why Capitalism Triumphs in the West and Fails EVERYWHERE ELSE (Basic Books $1^{\text {st }}$ ed. 2000).

${ }^{54}$ Michael Sherraden, Assets and the Poor: A New American Welfare Policy (M.E. Sharpe 1991). Sherraden argues that public policies prevent welfare recipients from accumulating assets under the rules of the income-transfer programs, Id. at 6; while enabling the non-poor to build wealth and well-being through tax subsidies for homeownership, and for corporate and individual retirement pensions. Id. at 68 .

${ }^{55} I d$. at 101-105.

${ }^{56}$ Kathryn Edin recounts the decision by one woman who resigned her job as a nurse's aid just months shy of earning her certificate, in order to work in retail at [a big box store] where she would have the opportunity, after 3 years, to vest in a pension. Kathryn Edin, More Than Money: The Role of Assests in the Survival Strategies \& Material Well Being of the Poor, supra n. 54, at 206.
} 
ordinary understandings of real property, or of "place," or of capital, but pivotal nonetheless in individuals' capacity to function -- a car, a ladder, one's uniform. ${ }^{57}$

This is an important shift in attention to the wealth-building opportunities for low-income urban dwellers. For most of U.S. history, land was the ultimate asset and primary root of wealth. It was durable financially as well as physically, in the sense that land retained its value, it was legally secured by "property rules" and by due process, and it could generate wealth. Land in the Homesteading Acts era ${ }^{58}$ was the most highly generative asset: the source of political power in the early republic, and of self-sufficiency for households and economic development for communities. $^{59}$ But in today's economy, corporate capital has eclipsed land as the asset that confers autonomy, given its characteristics as highly generative, ${ }^{60}$ highly liquid and thus more disposable than real estate. Arguably it is even more legally secure than land, because business capital is not generally subject to comparable restrictions on alienability or specific use, or to eminent domain.

Imagine that instead of the fiscal illusion of public benefit from the proliferation of public/private redevelopments that deplete the jurisdiction's affordable housing stock, it were possible to make those who bear the burdens of dislocation, direct beneficiaries of the new project. $^{61}$ Imagine that local law directs or incentives the PPP to offer Equity Shares in the

${ }^{57}$ Id. at $217-219$

58 See generally Homestead Act of 1862, ch. 75, 12 Stat. 392 (1862), repealed by Act of Oct. 21, 1976 Pub. L. No. 94-579, 90 Stat. 2787 (1976).

59 Robert Hockett, A Jeffersonian Republic by Hamiltonian Means: Values, Constraints, and Finance in the Design of a Comprehensive and Contemporary "Ownership Society," 79 S. CAL. L. REV. 45, 99-104 (parsing early American land laws, from the Land Act of 1796 through the Homestead Acts of the nineteenth and early twentieth centuries, for their wealth-building import).

$60 \mathrm{Id}$. at 140 ("[H]istoric average annual returns on equity cluster around 6.6\%-7.2\%." (citing JEREMY J. SIEGEL, STOCKS FOR THE LONG RUN 11 (2d ed. 1998)).

${ }^{61}$ Such a project could sensibly entail requirements for the production of affordable housing elsewhere: a trade of one occupancy right for another comparable one, akin to the rule undergirding the Uniform Relocation Act. 
value-adding redevelopment to all the residents in the project impact area. This approach would provide much-needed modernization to the public comment practices of land use planning, and offer direct benefits to the affected city residents. Community Equity Shareholding as I describe it here would allow public/private redevelopment of urban community space to be bargained for and approved by the affected city residents, so that the community may benefit as a whole, and the members of the displaced population receive meaningful equity shares in the value added redevelopment. This approach would modernize resident participation strategies in urban land use planning and regulation extant now for nearly sixty years, by recognizing with market value the legitimate interests of residents in the space they co-inhabit.

\section{Bargaining for Beneficiary Status: Community Benefit Agreements}

Existing law has partially recognized aspects of these interests and the ineffective remedies offered for prospective displacees in the path of urban redevelopment.

Recognition of community interests in land use decisions comes chiefly in the form of nominal public participation rights by residents in the path of prospective redevelopment projects. ${ }^{62}$ Public notice and hearing processes, or consultation via charette, offer a veneer of inclusive deliberation yet exclude residents as stakeholders in the decision about community destruction. ${ }^{63}$ These processes offer no avenue to shift the burden allocation. ${ }^{64}$ Public hearings occur too late

62 See generally Alejandro E. Camacho, Mustering the Missing Voices: A Collaborative Model for Fostering Equality, Community Involvement and Adaptive Planning in Land Use Decisions, Installment Two, 24 STAN. ENVTL. L.J. 269 (2005); Audrey G. McFarlane, When Inclusion Leads to Exclusion: The Uncharted Terrain of Community Participation in Economic Development, 66 BROOK. L. REV 861, 868-91 (2001) (reviewing resident participation requirements under various government programs for urban redevelopment from 1949 to the present).

63 Id. An array of successful resident-controlled redevelopment is discussed in, e.g., HEATHER MCCULLOCH WITH Lisa Robinson, SHARING THE WEALTH: RESIDENT OWNERSHIP MECHANISMS, A POLICYLINK REPORT (2001), available at http://www.policylink.org/pdfs/ROMS.pdf; Benjamin B. Quinones, Redevelopment Redefined: Revitalizing the City with Resident Control, 27 U. MICH. J. L. REFORM 689, 753-58, 767 (discussing the Dudley Street Neighborhood Initiative in Boston and other examples of resident controlled redevelopment).

${ }^{64}$ Jon C. Teaford, Urban Renewal and its Aftermath, 11 HousING POL'Y DEBATE 443, 446 (2000) (relating the evisceration of: an Italian enclave in Boston's West End, a Croatian-American community in the Vaughan Street area in Portland, Oregon; displacement of the residents of Philadelphia's Eastwick project, the inhabitants of New 
and address too little for the incorporation of the community's interests into the project.

In recent years, Community Benefits Agreements (CBAs) have garnered significant interest among communities and their advocates, precisely because they redress this procedural insufficiency, and produce community-inclusive modifications to proposed redevelopment projects. Typically a community benefit agreement is a private contract negotiated between a prospective developer and representatives of affected communities. ${ }^{65}$ Several agreements have been reached whose terms and process show promise for this as one strategy to ameliorate many of the inequitable results of public/private redevelopments. Under a CBA, community parties gain promises modifying original development concepts, including affordable housing, employment participation, open space or other amenities, monitoring provisions, and potential remedies for breach. Practically speaking it is a device limited in availability to those communities already served by established organizations that can muster resources and make their way to the bargaining table, either before local officials and private developers have made the deal, or in sufficiently muscular coalition to effect modifications. In practice, a CBA may have particular utility in relation to very large projects affecting multiple neighborhoods, faith

York's West Village, the Mexican American residents of Los Angeles' Bunker Hill, and the inhabitants of San Francisco's Western Addition). Id. at 446-49. The Atlantic Yards project began after its targeted site had begun to gentrify, but it appears to have encompassed a substantial number of low-income households and minority households in 2000. See Jung Kim \& Gustav Peebles, Estimated Fiscal Impact of Forest City Ratner's BROOKLYN ARENA AND 17 High RISE DEVELOPMENT ON NYC AND NYS TREASURIES 14-15 (2004); Develop Don't Destroy Brooklyn, Response to the Atlantic Yards Arena and Redevelopment Project Blight Study Contained within the General Project Plan, 2006, http://www.dddb.net/documents/environmental/DEIS/testimony/DDDBBlightResponse.pdf, at 3.. Tenants have gotten "the hardest hit," losing rent-stabilized apartments with no guarantee of relocation assistance and no real option but to leave their community. Deborah Kolben, Nets Site Renters Left Out in Eminent Domain Payouts, THE BROOKLYN PAPER, Feb. 3, 2006; see also Deborah Kolben, Market for Sellers, Not Renters, THE BroOKLYN PAPER, Feb. 3, 2006 (reporting tenants complaints regarding impending dislocation and the absence of assured relocation assistance).

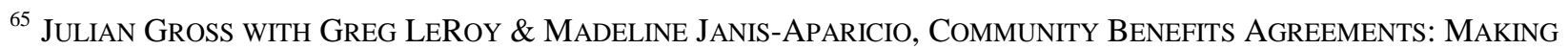
DeVelopment Projects AcCountable 9-10 (Good Jobs First \& the California Partnership for Working Families 2005), available at www.goodjobsfirst.org/pdf. 
groups and unions; and conversely, require significant delegation by residents to community agents to navigate the coalition, negotiate and monitor the CBA. More worrisome, a few case studies of CBAs caution that some of those organizations that can muster themselves to the table may be insufficiently representative of the community facing displacement. ${ }^{66}$

CBAs suffer from two significant drawbacks then. The first is uncertainty as to enforceability as contract. Commentators have raised questions whether the community members have standing to enforce the terms in the event of breach. Doctrinally and factually the issue is one of actual consideration. If the community signatories assent, courts may treat CBAs as a bilateral agreement with beneficial promises to third parties. The CBA does not alter the legal structure of the public/private arrangement; it remains fundamentally contractual. It seeks to involve additional community parties who otherwise would be excluded from crafting the character and benefit of the proposed development, thus the bilateral negotiation becomes multilateral.

A second difficulty is that the CBA's hallmark - its community- representativeness - may modify the political bargaining essence of the public/private partnership by degree, but not in kind. This raises a political economy caution, because Community Benefits Agreements do not necessarily assure an inclusive or transparent process for neighborhood residents. Several recent CBAs have come under stinging criticism for insufficiently inclusive representation. For example, the Bronx Terminal Market CBA, negotiated in 2006, involved no grassroots community organizations. ${ }^{67}$ Instead, eighteen community groups were handpicked by the

\footnotetext{
${ }^{66}$ Patricia Salkin, Amy Lavine, Negotiating for Social Justice and the Promise of Community Benefits Agreements: Case Studies of Current and Developing Agreements, 17 WTR-J. AFF. HsG. \& COMM. DEV. L. 113 (2008).

${ }^{67}$ Heather Haddon, Terminal Market Deal Criticized, 19 Norwood News 4, Feb. 23, 2006 - March 8, 2006, available at http://www.bronxmall.com/norwoodnews/past/022306/news/N60223page1.html; Jimmy Vielkind, How
} 
borough president, and then were given just 30 days to draft an agreement. They received no technical assistance in a process that, in cities around the U.S., would include enforceable developer commitments to incorporate affordable housing, local and minority hiring, job training, and living wage provisions, and often, community facilities such as day care centers and parks. ${ }^{68}$ In the Bronx, however, the organizations did not see the completed CBA until the morning of the city council's vote to approve the development plans. At that point, seven of the organizations refused to sign, ${ }^{69}$ but the plan was approved nonetheless. The Yankee Stadium CBA lacked any pretense of being negotiated or signed by any community groups. Instead, it expressed the agreement between the Yankees, the Bronx borough president and the Bronx delegation of the New York City Council. ${ }^{70}$ Critics worry about the true representativeness of groups who step forward to participate. ${ }^{71}$

To achieve equitable resident benefit from redevelopment, communities need a device that will transform association and democratic participation into ownership-spreading through equity participations. Real resident benefit from urban redevelopment requires three things: (1) recognition of the significant investments of the residents of poor communities which stake them

to Mediate Manhattanville: A New Neogiating Partner is Born, CiтY LiMits WeEKLY, Dec. 4 2006, available at http://citylimits.org/content/articlees/viewarticle,cfm?article_id=3223.

${ }^{68}$ Gross, supra note 65; Harold Meyerson, No Justice, No Growth: How Los Angeles is Making Big-Time Developers Create Decent Jobs, THE AMERICAN ProsPeCt, Oct. 22, 2006.

${ }^{69}$ Haddon, op cit.

${ }^{70}$ Patricia E. Salkin, Community Benefits Agreements: Opportunities and Traps for Developers, Municipalities and Community Organizations, 59 PlanNING \& ENV. LAW 3 (2007).

71 "Groups pop up and you're not sure who they represent," said Patricia A. Jones, the co-chairwoman of the Manhattan Community Board 9 task force on Columbia University's expansion in Manhattanville. Terry Pristin, In Major Projects Agreeing Not to Disagree, N.Y. TIMES, June 14, 2006, available at http://www.nytimes.com/2006/06/14/realestate/commercial/14agree.html. A potentially related concern by some observers is the capacity of community coalitions to participate constructively. Good Jobs First and Policy Link, two nonprofit think tanks in the forefront of promoting community benefit and equitable development, each advocate significant technical assistance as a necessary predicate to the effective bargaining position of community parties to CBAs. See Gross, supra n.65 at __; ShARING THE WEALTH: RESIDENT OWNERSHIP MECHANISMS, supra note 68 . 
in their collectively inhabited neighborhood space, ${ }^{72}$ (2) expression of residents' stakes in the form of a correlative claim on the public resources committed to the redevelopment; and (3) a pragmatic means for crediting residents' claims within the relevant time frames of decision and benefit as to the land use planning, public funding and decision-making of the redevelopment project. Shares in joint economic undertakings can fit this bill.

\section{B. Community Based Joint Ventures}

\section{Joint Ventures in Ownership}

If corporate capital vehicles are useful for upper income folks to build assets, then surely that can be true for low-wealth communities as well. Community enterprises that engage poor people as stakeholders can formulate cooperative relationships in ways that extend the socialcapital of the collective undertaking. Chronically poor people in the United States living in starkly segregated enclaves are not likely to know people with the kind of social leverage that can help them gain freedom from poverty. The sister who provides grey-market child care may permit one to attend school, but not to assist in gaining admission to a school on a higher rung in the opportunity structure. That kind of leverage may not be within the kin and friendship networks of the poorest urban communities. In the United States, a chronically poor person's chances of securing such leverage from social capital are greater where one's community includes some people not like him or her. ${ }^{73}$

Community development corporations (CDCs) have been an important engine of community-based self-help for 30 years. ${ }^{74}$ CDCs have been criticized as no longer accountable

\footnotetext{
${ }^{72}$ Bezdek, supra n. 9, at 86-90.

${ }_{73}$ Briggs, supra note 44 , at 179

74 See generally Michael H. Schill, Assessing the Role of Community Development Corporations in Inner City Economic Development, 22 N.Y.U. REV. L. \& Soc. CHANGE 753, 766-72 (1997) (giving a brief history and overview of CDCs' involvement in community-based economic development); Norman J. Glickman \& Lisa J.
} 
to the communities where they engage in revitalization, dependent on a mix of public and foundation contracts, grants and loans and consequently more responsive to funders' views than to their purported community base. ${ }^{75}$ Despite occasional critiques, numerous CDCs have managed to scrap their way further into market-based practices in service of their community stakeholders. Some CDCs are contemplating issuing shares - to enable their stakeholders to be shareholders.

One particularly important path is the creation of enterprises formed with equity interests. Examples include the New Community CDC of Newark, New Jersey, which developed a supermarket; ${ }^{76}$ the Kansas City CDC that owns a cement block factory; child care centers, health

care facilities. ${ }^{77}$ Preliminary results from the Market Creek Plaza "People's IPO" demonstrate the capacity of community enterprises to engage poor people as shareholders in successful enterprises.

\section{The People's IPO: Market Creek Plaza}

The most robust model thus far for community equity shareholding is illustrated by Market Creek Plaza, an enterprise to revitalize a 20 acre industrial site in southeastern San Diego. The Market Creek Plaza enterprise was formed by a nonprofit organization and designed

Servon, More than Bricks and Sticks: Five Components of Community Development Corporation Capacity, 9 HOUSING POL'y DEBATE 497, 504-512 (1998).

${ }^{75}$ Randy Stoecker, The CDC Model of Urban Redevelopment: A Critique and an Alternative, 19 J. URBAN AFF. 1, 14 (1997); cf. Rachel G. Bratt, CDCs: Contributions Outweigh Contradictions, a Reply to Randy Stoecker, $19 \mathrm{~J}$. URBAN AFF. 23, 23-28 (1997).

${ }^{76}$ Schill, supra n. 79 at 771-772. (The CEC leases the land and provided a share of the capital; day to day management of the company is by a separate supermarket corporation, with the CDC providing support services to augment hiring, product selection and security. Members of the CDC sit on the board of the store corporation.)

${ }_{77}^{7}$ See e.g. Peter Pitegoff, Child Care Enterprise, Community Development, and Work, 81 GEORGETOWN L. J. 1897 (1993); Inserra, ANne, Maureen Conway, AND John Rodat, CoOperative Home Care Associates: A CaSe Study of a Sectoral Employment DeVElopment ApProach (The Aspen Institute 2002); Sharing the WEALTH, supra n. 68. 
for the express purpose of engaging residents of the low-wealth Diamond Neighborhoods in the process and benefits of the project. $^{78}$ In July 2006, Market Creek Partners offered 50,000 shares to local community residents at $\$ 10$ a share, with a minimum investment of $\$ 200$. At the time of the offering, Diamond Neighborhood residents had a median income of $\$ 32,800$, and nearly onethird of the households earned less than $\$ 20,000$ each year. ${ }^{79}$ Market Creek is now a thriving, \$45 million commercial enterprise, making distributions to its investors. Its anchor tenant is a full service supermarket - the first major grocer to locate in the area in thirty years. ${ }^{80}$ The revitalization now includes a library and performing arts center, an elementary science center, a state-of-the-art high school, ethnic restaurants, and a conference center. In the next phase, more than 800 affordable housing units will be built on the site. ${ }^{81}$

Purchasers become Diamond Community Investors and members of Market Creek Partners, LLC. As members, each purchaser is entitled to cast one vote, regardless of the number of units purchased, in the election of the company's advisory board. ${ }^{82}$ The minimum offering

\footnotetext{
${ }^{78}$ The project was spearheaded by the Jacobs Center for Neighborhood Innovation (JCNI), a California nonprofit established in 1995 by the Jacobs Family Foundation. Urban Land Institute, Market Creek Plaza, http://www.uli.org/AM/Template.cfm?Section=Home\&CONTENTID=109950\&TEMPLATE=/CM/ContentDisplay .cfm (last visited ...). Issuance of shares requires compliance with federal and state securities laws. Market Creek Plaza was designed to qualify for the federal intrastate exemption for security offerings. 15 U.S.C.A. $§ 77 c(a)(11)$. The safe harbor of Rule 147 further requires the issuer, offerors and purchasers all to be residents of the state of offer. 17 C.F.R. $\$ 230.147$ (2008).

${ }^{79}$ Id. Urban Land Institute, Market Creek Plaza

${ }^{80}$ Lisa Robinson, Market Creek Plaza: Toward Resident Ownership of Neighborhood Change, POLICYLINK CASE STUDY 12 (2005).

81 Lori Weisberg, Affordability by Design, SAN DIEGO UnION-TRIB., June 10, 2007, at D1.

${ }^{82}$ Market Creek Partners, LLC is managed by Diamond Management, Inc., and it is composed of the following members: JCNI, the Neighborhood Unity Foundation (NUF), and Diamond Community Investors. Diamond Management was incorporated for the purpose of managing Market Creek Partners, LLC, and it is entirely owned by JCNI. JCNI is a non-profit public benefit corporation organized in California that engages in public-private partnerships intended to promote sustainable communities by transferring ownership interests in community development projects to local residents. NUF is also a nonprofit public benefit corporation in California that was organized to benefit the Diamond Neighborhoods. Diamond Community Investors are the shareholders from the local community. Market Creek Partners, LLC, Offering Circular, at 2 (2005).
} 
amount was $\$ 250,000$, and the maximum offering amount was $\$ 500,000 .^{83}$ These terms enabled local residents to own up to a $20 \%$ interest in the venture, while the Jacobs Center for Neighborhood Innovation (JCNI) retained a 60\% interest, and the Neighborhood Unity Foundation (NUF), retained the remaining $20 \%$ interest. $^{84}$ The project is intended to transfer complete ownership to local residents within 12 years.

Shareholder Qualification. Market Creek Partners established strict eligibility criteria for all purchasers. ${ }^{85}$ Most importantly, each purchaser was required to be a resident of the revitalization district as well as a state resident. ${ }^{86}$ The purchaser had either to reside currently or previously to have resided in one of eight designated "Diamond Neighborhoods." 87 Shares' initial purchase and resale were limited to "Diamond Neighborhood Stakeholders" as defined by residency and investment intention. ${ }^{88}$

To educate its prospective investors to make informed investment decisions in a commercial real estate venture, Market Creek Partners transformed its 200-page prospectus into

83 The offering achieved its maximum offering amount of $\$ 500,000$. Doug Sherwin, Community Members Purchase Shares of Market Creek IPO, SAN DIEGO DaILY TRANSCRIPT, Nov. 13, 2006.

84 Market Creek's operating agreement provided for an allocation of income to members/shareholders in the following order of priority: (1) DCI units-a 10\% return, (2) NUF-a 10\% return, and (3) JCNI and DMI units-a $7 \%$ return. Following this order of allocation, any remaining balance of income was to be distributed to the company's members in proportion to the total outstanding units. A distribution to Diamond Community Investors was subject to the manager's discretion to withhold up to $5 \%$ of any distribution for a repurchase reserve. Market Creek Partners, LLC, Offering Circular, at 38 (2005).

${ }^{85}$ Both to direct the benefits of the offering to the local community, as well as to ensure compliance with the requirements of an exempt intrastate offering.

${ }_{86}$ Market Creek Plaza was designed to qualify for the federal intrastate exemption. State residence is thus essential to qualify for the transaction exemption from Section 5's registration requirement for intrastate security offerings. 15 U.S.C.A. $\$ 77 \mathrm{c}(\mathrm{a})(11)$. Rule 147 further requires the issuer, offerors and purchasers all to be residents of the state of offer. 17 C.F.R. $\$ 230.147$ (2008).

${ }^{87}$ In addition, certain others with a demonstrated commitment to the Diamond Neighborhoods were also eligible to purchase DCI units, including owners of businesses within the eight neighborhoods and certain other entities and individuals. Market Creek Partners, LLC, Offering Circular, at iv (2005).

88 Id. at 39. The offering's subscription agreement included "Sustainability Standards," which required a prospective investor to make certain declarations regarding her state of residency, to affirm her intent to hold the securities for investment purposes for a period of no less than nine months, and to acknowledge that the securities were subject to resale restrictions. Id. at iii. 
a 20-page executive summary that included pictures and graphs to answer the investors' most frequently asked questions. The company's business model entailed involving Diamond Community residents to determine the types of businesses and services the residents hoped would be developed at Market Creek Plaza. ${ }^{89}$

Community Benefit. The employment-related local-resident benefits of this joint venture model are similar to those sought under many CBAs: local hiring and minority contracting. Over $90 \%$ of the initial employees at the supermarket were hired from the community. These jobs are unionized and include living wages, health care, and pension plans. Some 69 percent of the construction contracts for Market Creek Plaza were awarded to local minority-owned enterprises, totaling $\$ 7.1$ million..$^{90}$

Additional benefits are potentially still more transformative. As a catalyst for civic participation, the project involved 2,000 adults and over 1,000 youth, who have participated in land planning, leasing, marketing, research, advocacy, and ownership design. Extensive use of cross-cultural community teams has been a consistent feature of project implementation. ${ }^{91}$ In addition, the project provides for future neighborhood reinvestment, through the residents' locally controlled foundation, chartered to grant a portion of the profits from the development back into the neighborhood. ${ }^{92}$

89 Anne Stuhldreher, The People's IPO, StAn. Soc. InNOvation Rev. (2007), available at http://www.newamerica.net/publications/articles/2007/the_people_s_ipo_4486; Market Creek Plaza website, Community Teams, available at http://www.marketcreek.com/mcp_teams_co.html.

${ }_{90}$ PolicyLink, Market Creek Plaza: Overview, http://www.policylink.org/Projects/MarketCreek/ (last visited October 21, 2008).

${ }^{91} I d$.

${ }^{92} I d$. 
It is time to activate a stage of cooperative capitalism beyond the familiar examples that include community development corporations (CDCs), microlending, community development financial institutions (CDFIs). ${ }^{93}$ A community enterprise whose shareholders include the residents when the development project is seeking municipal approvals, and may grow to include incoming residents, is potentially an economic collaboration in which shareholders enjoy equal political and economic rights in the entity, more concretely and manageably than in the wider city polity.

93 Instances of many of these models are described in SHARING THE WEALTH: RESIDENT OWNERSHIP MECHANISMS, 2001, prepared by PolicyLink in collaboration with FNMA and HUD, available at http://www.policylink.org/pdfs/ROMs.pdf. Community-rooted corporations, formed as nonprofits, are importantly not as nimble nor its capital quite so mobile, due to CDC corporate missions and internal governance procedures. In this way they may be distinguished from private companies. 


\section{FROM STAKEHOLDERS TO SHAREHOLDERS: Community Equity Shares}

The fundamental premise of Community Equity Shareholding is that community members not lose their substantial investments in their place, nor have their residency terminated by local government land use practices that transfer public resources into largely private redevelopment of residences for others, unless and until residents have approved the redevelopment; and unless and until residents receive shares in the economic value of the project. Such approval might be accompanied by an agreement to exchange their community residency interests for an equity stake in the benefits generated by the new development. Such an equity stake could take the form of an alienable right to comparable replacement housing in the new development, or to shares in the increased economic value justifying the public participation in the project and generated by it over time, or both.

This set of property interests can be recognized through reforms of the redevelopment planning requirements of state enabling statutes. The result is a process that invests residents with rights to consent to development beforehand, and to a share in the benefits of the deal in which the locality partnered.

Community equity shares make use of a familiar capital vehicle to render visible the residents' stakes in the community. Residents receive shares in the real estate venture - in effect, becoming members of the joint venture in urban redevelopment.

\section{A. A Responsive Framework}

The Community Equity Shares concept offers a responsive framework to the inequitable allocations inherent in redevelopment theory and practice. It embodies three crucial principles missing from contemporary PPP practice: the principles of Fair Share - fair and inclusive shares 
in the wealth-creation facilitated by public investment; Governance - a right of residents of the targeted development zone to vote on the character of the planned redevelopment; and Collective Action - a framework to facilitate the recognition of the collective social capital of the community, and intentionality about exchanging it for the development sought by the public/private partnership.

\section{Fair Shares}

Most analyses of the inequitable development problem perpetuates the invisibility of community stakes, proposing to tweak eminent domain doctrine, but limiting redress to title owners of affected properties. One straightforward approach is to increase the payments made to displaced homeowners by monetizing the subjective value of property taken by eminent domain ("homeowner surplus") to deal with the obvious problem that forced sales at fair market value in severely disinvested neighborhoods fail to compensate displaced long-term owners for "the subjective element." While legal determinations of just compensation almost universally reject paying for the subjective value attributed by the owner, in some circumstances this seems particularly unjust. Some legal scholars have developed proposals for the award of supplemental damages to long-term owners according to a legislated schedule reflecting length of tenure; ${ }^{94}$ and programs for self-assessed valuation. ${ }^{95}$ These analytic developments are important for the subset of residents in disinvested/development-targeted neighborhoods whom they reach.

Yet the continued exclusion of non-title owners provides no remedy for substantial numbers of persons, households and their communal interests, which will be destroyed by

\footnotetext{
94 Robert C. Ellickson, Alternatives to Zoning: Covenants, Nuisance Rules, and Fines as Land Use Controls, $40 \mathrm{U}$. CHI. L. REV. 681, 736 (1973).

95 Lee Anne Fennell, Taking Eminent Domain Apart, 2004 Mich. St. L. ReV. 957, 995-1002. Fennell limits her proposal for such landowner protection to instances of public taking for private transfer where the public use is unclear. $I d$. at 995.
} 
redevelopment projects that uproot them.

\section{Governance}

The second element is the incorporation of a governance principle, to effect community consent and control regarding redevelopment decisions in their backyards. ${ }^{96}$ Recently, Michael Heller and Roderick Hills proposed to make land assembly the proper subject of the consent of the residents whose neighborhoods were in need of redevelopment, through Land Assembly Districts. ${ }^{97}$ The model of governance they envision is direct control by referendum. Pursuant to local legislation, the local government would construct consent to the land assembly by declaring a proposed Land Assembly District, and putting the detailed purchase proposal to a referendum of the intended condemnees. ${ }^{98}$

\section{Collective Action}

Collective action and community consent could be fostered through voluntary land assembly, particularly if practiced by communities as a strategy to coordinate with, and benefit from, market-based redevelopment that threatens to overtake severely deteriorated, underinvested neighborhoods. ${ }^{99}$ Such an approach would go a long way to reconnect disinvested communities to thriving realty markets, by addressing the interrelated problems of land assembly

96 Quinones, supra note_68 at 698 (advocating supermajority resident representation on the board). For a related discussion of two case studies of "community-sponsored" planning in New York City, see Amy Widman, Replacing Politics with Democracy: A Proposal for Community Planning in New York City and Beyond, 11 J.L. \& POL'Y 135, 150-73 (2002) (proposing legislative change to equalize the necessary resources and negotiating power among communities and encourage inclusive processes).

97 Michael Heller \& Rick Hills, Land Assembly Districts, 121 HARV. L. REV. 1465 (2008).

$98 \mathrm{Id}$. at 1490 . While this process could be imposed upon the residents who may not have sought this particular redevelopment, the collective decision-making is similar to that within condominium associations, and labor unions. Heller \& Hills are not entirely clear as to whether they would limit the procedure to landowners, homeowners, or "neighbors"; and in the event the LAD were rejected, since the rest of the eminent domain process would still be available, they structure a procedural opportunity that could be very important to communities that avail themselves of it, but not an absolute bar to redevelopment. Id. at 1491-1492.

99 James Kelly, We Shall Not Be Moved: Residency as a Property Rule Entitlement, 80 ST JOHNS L REV 923 (2006). 
and cost posed to development-seeking cities by fragmented and diversely held titles.

Nonetheless, many communities targeted by PPPs do not have the political organization or technical support to see the development coming and to act in time. Where communities lack the leverage to negotiate meaningful promises from developers, their stakes in the urban space they share should be protected from expropriation.

Separately these principles are important advances for instantiating the equities of longtime residents of the islands of disinvestment in our comeback cities. Yet alone, each is insufficient to protect community residents' interests from destruction by public/private redevelopment projects.

\section{B. Residents' Community Capital Stakes Expressed as Limited Property Right}

Residents' stakes in their community ought to be protected from expropriation by public agencies when the urban space the community occupies is taken for public/private redevelopment. Legal security is essential within our system of rights over the control of resources. ${ }^{100}$ Protection of residents' interests by property rules, rather than the liability rules of contract or tort, is appropriate to afford residents the necessary sphere of choice not to be dispossessed and disentitled to the community they have made in their shared location. ${ }^{101}$ Applying these principles to the contested urban neighborhood, the "social capital" that entwine viable neighborhoods can be rendered cognizable in these respects by allocating shares in the

\footnotetext{
${ }^{100}$ Bezdek, supra n. 9 at 74-79. A resource or material opportunity may be viewed in more specific legal or fiscal terms as an "asset" to the degree that it possesses asset-like qualities. Is it generative of more resources? How readily can it be exchanged or converted into money? Greater liquidity and generative capability confer greater choice and autonomy on the asset's holder. Resources are more like assets to the extent they are durable and foster reliance: that is, to the extent they are secure in a physical or legal sense.

101 Property rules confer upon the holder of a property right the power to determine whether to transfer the protected asset and at what price. By contrast, liability rules do not give the holder injunctive relief, but only the remedy of damages for a nonconsensual transfer, typically at a price set by a third party such as a court or legislature. See Guido Calabresi \& A. Douglas Melamed, Property Rules, Liability Rules, and Inalienability: One View of the; Cathedral, 85 HARV. L. REV. 1089, 1092 (1972).
} 
targeted redevelopment enterprise.

This is not a set of interests to be limited by eminent domain doctrine. Eminent domain rules would be unaffected: for residents in the targeted redevelopment site who own homes or businesses, ordinary condemnation and compensation principles and procedures would continue to apply. Community equity shares run to residents. Limiting CESs to natural persons with established residency would not include absentee owners of rental or commercial properties, nor to entities. While the local ordinance would need to establish an appropriate residency requirement of sufficient length to predate rumors of redevelopment and thus speculative inmoving, there is no conceptual reason to limit proof of residency to leaseholders: each adult in a household would be entitled to his or her own CES; and so should neighborhood residents who occupy transitional housing or patronize homeless shelters, or can otherwise demonstrate sufficient tenure in nontraditional abodes. ${ }^{102}$

Accordingly, the allocation of Homestead Stakes would recognize the interests of lessees, commensurate with their common-law entitlement to property. Consider the tenant who has rented the same apartment for many years, and built up friendships and networks of support unrelated to the economic value of her year-to-year lease. Land assembly will eliminate the apartment building and dispossess the tenant of her neighborhood. There is no compelling or obvious reason why the lessee should not have an equal vote in a decision so fundamentally affecting her interest.

102 In many urban communities, this group will include individuals who are homeless -- who must sleep in shelters or on the streets within the targeted area - and street people - those who spend most of their time on the streets because of inadequate private space or who work in the informal economy on the streets, see MARGARET KAHN, Brave New Neighborhood: The Privatization of Public Space (Routledge 2004); Jeremy Waldron, Homelessness and Community, 2000 U. TORONTO L. J. 50. 


\section{Operational Details: Resident Homestead Stakes \& Community Equity Shares}

The elements of fair share, governance and collective action can be unified and reinvigorated in the form of two new interests: the Homestead Stake, and the Community Equity Share. Shares could be held either in an autonomous Community Equity Company ("CEC"), or in the project development entity itself. Direct shareholding reflects community residents' steadfastness in their home space.

At the core of the CEC would be the Community Homestead Stake, created by reforms to existing statutory structures. The Homestead stake, embodying the Governance principle, would assure that persons who hold legally recognizable interests in their community, should decide collectively whether the land ought to be assembled into a larger parcel for redevelopment and put to the proposed uses.

Each resident of the geographic area identified for the redevelopment project would receive one share in the CEC, the Homestead Stake. The Homestead Stake would give its owner specific rights to participate in the development decision-making; most importantly, to vote on the constitutive question of the proposed redevelopment plan. State and local redevelopment statutes would require the redevelopment agency to submit proposed redevelopment for vote by the affected Community Homestead Stake holders-effectively conducting a localized referendum on redevelopment proposals, initiated either by the government agency or the subject of an application by private developers. Property law ought to be available to retrofit community interests into a shared-ownership vehicle. One rough analogy would be to a condominium conversion.

The legal right to vote on the question would likely enhance opportunities for the community to bargain with the public/private development partners for particular community 
benefits. Efforts to forge agreements between affected residents and developers or public development agencies have been undertaken from Seattle to New York in order to mitigate the harmful effects of aggressive developments and secure specific concessions. ${ }^{103}$ However, many communities are unable to muster in time to get to the bargaining table. The Homestead Stake would correct this inequity. Similarly, such facilitated collective action may promote residents' self-protection from speculators in advance of redevelopment activity.

The rules for allocation of Homestead Shares and the operation of the Community Equity Corporation are designed to ensure that the people most affected by the project's need for land assembly, the residents, have a collective veto over whether the project should proceed upon the larger parcel that their displacement will allow. The justice of this quid pro quo is especially apparent where the proffered rationale for the redevelopment is to improve the neighborhood - to remove "blight" or replace aging infrastructure. The governance rule accompanies the "fair share' principal, so that those who will bear the direct costs of the project can decide for themselves whether they want the proffered improvement.

Allocation of Homestead Stakes should instantiate the interests of lessees as well and commensurate with their common-law entitlement to property, since leaseholds are property interests as time-honored as the fee simple absolute. Consider the tenant who has rented the same apartment for many years, and built up friendships and networks of support unrelated to the economic value of her year-to-year lease. Land assembly will eliminate the apartment building

\footnotetext{
${ }^{103}$ See Sheila Muto, Residents Have Their Say on LAX Expansion Plans, WALL ST. J., Dec. 15, 2004, at _? (discussing the community benefit agreement with the Los Angeles airport which provides for environmental mitigation, noise reduction, and airport related work; negotiations in Seattle between a public-interest coalition, city officials, and a company planning the downtown development of a biotechnology hub over affordable housing, employment, and environmental issues; and the pressure on Columbia University in New York by neighborhood, business, and civic leaders to "help create low-income housing in the West Harlem area where [it] has proposed to expand"). Community Benefits Campaigns are currently underway in Denver, Miami, Milwaukee, San Diego, San Jose, and New Haven. See also Julian Gross ET AL., Community BenEFITS AgREEMENTS: MAKING DEVELOPMENT PROJECTS ACCOUNTABLE 5 (2005).
} 
and dispossess the tenant of her neighborhood. There is no compelling or obvious reason why the lessee should not have an equal vote in a decision so fundamentally affecting her interest. ${ }^{104}$ Recognizing the stakes of tenants addresses the 'Tyranny of the majority' concern of Federalist 10 that, as one shrinks the size of a jurisdiction, one increases the danger that the majority will enact rules solely benefiting itself at the expense of a minority for no better reason than that the majority can. This is exactly the situation when the only players in the land assembly and use decisions are title holders, many whose connections to the neighborhood are economic only.

By facilitating the collective action of all the residents, not just real property owners, the Community Equity Shares provide ballast to the largest landowners in the community, likely to be institutions such as Real Estate Investment Trusts, corporate landowners, and speculators, who hold land primarily as an investment. ${ }^{105}$

In articulating rules of land use law, courts have been skeptical of neighborhood control over zoning regulations, precisely out of concern to protect the minority against a majority of

104 The same may well be true for transient and homeless people, who while having no abode, nonetheless have legal residency for voting purposes. See e.g., Coalition for the Homeless v. Jensen, 187 A.D.2d 582 (N.Y. App. Div. 1992) (holding that a state requirement that people live in a traditional dwelling in order to vote placed an unconstitutional constraint on the voting rights of homeless persons); Fischer v. Stout, 741 P.2d 217 (Alaska 1987) (ruling that when registering to vote, homeless people may designate a shelter, park, or street corner as their residence); Collier v. Menzel, 221 CalRptr. 110 (Ct. App. 1985) (finding that denying voter registration because applicants listed a city park as their residence violated the Equal Protection Clause of the Fourteenth Amendment).

${ }_{105}$ An individual owner within the targeted area who would calculate her interests differently and object to neighborhood decision to approve a deal, would have to choose between the FMV or the compensation forthcoming as part of that deal. An individual owner who would consent where the neighborhood refused to endorse a proposed project, would be in no worse position than if developers had never eyed the community. Compared to their entitlement under eminent domain compensation principles, institutional owners of real property are not disadvantaged by this allocation of voting rights, by virtue of the likelihood that they derive relatively little producer or consumer surplus from their holdings in the neighborhood above the land's fair market value. Heller and Hills argue that a landowner whose subjective value of her parcel is higher, is nonetheless better protected by the neighborhood control than by the municipality, deeming "remote" the risks that a particular land assembly district would ignore the interests of any subset of participants. See Heller \& Hills, supra note 102, at 1500-1503. 
neighbors willing to unite around the goal of restricting a nearby parcel's uses and so enhance the value of their own land at the expense of the burdened parcel owner. ${ }^{106}$

The narrowness of the Homestead Stake avoids the doctrinal categories by which courts have sought to limit the power of neighborhoods to impose new zoning restrictions on parcels for selfish reasons. Generally, neighbors can approve a variance from preexisting restrictions on a parcel - but they cannot impose a new restriction. ${ }^{107}$ By limiting the vote associated with the homestead stake to the up-or-down question on the project, any bargaining as to the substantive provisions of the project that provide community benefits - some of which might be viewed as new use restrictions - remain collateral to the neighbors' decision waive extent zoning rules.

This structure simplifies the decision to the narrow question, for or against the use of land use and assembly powers vis-à-vis a parcel, or not. This segregates the up or down vote from the several differences in interest and position that might divide a community into antagonistic factions as to land tenure and other established economic networks, as well as service provision and potential employment or housing opportunities in the proposed new development.

In comparison, other community-level devices, such as business improvement districts (BIDs) having broader functions, can more readily create risks of majoritarian exploitation. BIDs for example provide a range of services from security, street cleaning, parking facilities, signage, and public relations, to the owners of land within their boundaries. Owners may be

\footnotetext{
${ }^{106}$ See generally Donald J. Kochan, "Public Use" and the Independent Judiciary: Condemnation in an InterestGroup Perspective, 3 Tex. Rev. L. \& Pol. 49 (1998) (describing special interest politics in the context of eminent domain). See Eubank v. City of Richmond, 226 U.S. 137, 143-45 (1912) (striking down an ordinance allowing a two-thirds vote of neighbors to draw a building line because the ordinance "enables the convenience or purpose of one set of property owners to control the property right of others").

${ }^{107}$ Under the nondelegation doctrine, the local legislature cannot delegate its zoning power to the neighbors, because this power is essentially legislative in character. Id.; see also Asmara Tekle Johnson, Privatizing Eminent Domain: The Delegation of a Very Public Power to Private, Non-Profit and Charitable Corporations, 56 AM. U. L. REV. 455, 460-67 (2007) (describing the private nondelegation doctrine in the context of eminent domain).
} 
affected in divergent ways that foster contention in the community and difficulty with BID governance. $^{108}$

\section{The Community Equity Corporation: A Vehicle for Collective Exercise of Resident Homestead Stakes}

This proposal would also facilitate the residents' ability to overcome barriers to collective action, and thereby avoid selling their neighborhood for an inequitable return. Local jurisdictions would recognize rights of residents facing redevelopment displacement, in effect permitting them to exchange their legitimate interests in the community for shares in the equity and profit from the redevelopment deal that displaces them. This new right would be created by statute, authorizing the formation of a CEC, establishing minimum requirements for shares, and identifying the terms of residence that qualify householders within the area targeted for redevelopment as Community Equity Shareholders.

Upon formation and assignment of shares, each shareholder would become a member of the Community Equity Corporation (CEC), a special entity with the power by majority vote to approve, or to veto, the proposed land assembly if the PPP does not offer an adequate value to the CEC.

This up or down vote would combine the residents' fragmented individual interests into a whole of sufficient value, economically and politically, that the neighbors have a means to bargain collectively over the surrender value of the space they occupy collectively. Generations of experience with PPPs show us what "bargaining" in isolation looks like: to developers, it is assembly value, but to the residents, it is home, community. ${ }^{109}$

\footnotetext{
${ }^{108}$ Heller \& Hill give the example of merchants who may want to increase the number of parking spaces for customers, while residential owners might want to cut down on traffic. Heller \& Hill, supra note 102, at 1500.

${ }^{109}$ Title holders in the area could be permitted to opt out of the CEC and receive their constitutional due.
} 
The CEC would provide a community-controlled vehicle to create and hold residents' equity shares in the value generated by the physical and economic redevelopment of their community, and provide the voting rights that accompany ownership in business entities. The CEC would reconfigure the "community interest corporation" demonstration program introduced in the Housing and Urban-Rural Recovery Act of 1983 modeled on employee stock ownership corporations; ${ }^{110}$ and retooled in the 1992 federal housing legislation to foster "indigenous community-based financial institutions."

The Community Equity Shares are conceptually distinct from rights in real property or condemnation awards that owners of businesses or others in the neighborhood may have. While this right may be conceptualized as individual in the way that shares in corporations are personal property, the essential interest it expresses is the joint interest to determination and benefit in the collectively inhabited geographic space.

The share would give its owner specific rights to participate in the development decisionmaking, and in distributions of profits, just as the other equity owners. Its holders would have the right, with all others holding similar Community Equity Shares, to participate as members in the development owner entity as a class of members holding Community Equity Shares in the increased value generated as equity shareholders. Redevelopment of the site would be contingent

110 Pub. L. No. 98-181, 97 Stat. 1153, 1172 (1983) (codified as amended at 42 U.S.C. $§ 5318$ (2000)) (creating the Neighborhood Development Demonstration, requiring the Secretary of Housing and Urban Development to "provid[e] Federal matching funds...to [local] organizations on the basis of the monetary support such organizations have received" from neighborhood sources); see also Harold A. McDougall, Affordable Housing for the 1990's, 20 U. MICH. J. L. REFORM 785-86 (1987).

111 Housing and Community Development Act of 1992, Pub. L. No. 102-550, 106 Stat. 3672 , 3859 (1992) (codified at 42 U.S.C. $\$ 5305$ (2000)). The aim of the demonstration program was to replicate the success of community development capital intermediaries such as South Shore Bank in Chicago and the Center for Community Self Help in Durham, North Carolina, to "improve access to capital for initiatives which benefit residents and businesses in targeted geographic areas." Id. § 853(b)(2) at 106 Stat. 3860. "Community investment corporations" were entities organized either as a depository institution of a nonprofit organization affiliated with a non-depository lending institution or regulated financial institution, whose primary mission was to revitalize a targeted geographic area, maintain "accountability to community residents" "through significant representation on its governing board and otherwise." Id. $\S 853(\mathrm{~b})(3)(\mathrm{D})$. The board would engage in development services, and have principals "who possess[ed] significant experience in lending and . . . development . . . " Id. 
upon an exchange of equity shares in the increased values being brought to market.

\section{Formation \& Operation}

To promote transparency of the redevelopment project plan and resulting PPP, it is necessary to plug the CEC into the city's power source: its planning process. Whatever the initial or ultimate project plan, the development will require some zoning change.

Who initiates the CEC? Formation of a Community Equity Corporation could be instigated by existing residents, by a local non-profit organization mobilizing to seek redevelopment partnerships. Its formation would be triggered when either city planning officials commence consideration of sites for public/private projects, or a developer proposes plans to the city and begins to negotiate for assistance with land assembly and related approvals.

How is it initiated? The preliminary application for development approvals would necessarily identify the boundaries of the intended development site and the lots within it. Every adult whose residence is within the boundaries would be entitled to notice at this early stage, of the development proposal, the formation of the CEC, the Homestead Stake and Community Shares. Because the specific boundaries of the development and affected lots may well change as the proposal is refined, residents of properties contiguous to the proposed site should be notified as well. The statute would provide for facilitated sessions to assure that CEC resident/members are well-informed about the CEC process, the development proposal, and the voting and equity rights of shareholding.

These meetings would likely be hosted by the local planning department, but could be augmented by community-based not-for-profit organizations. More assertive dissemination of notice such as door-to-door canvassing would be appropriate rather than reliance on postal or electronic notice to organizations on the planning department's radar. 
How does a CEC operate? One useful template would be the business improvement district (BID), of which there are already more than a thousand, authorized in more than forty states. Formed pursuant to state statute, local ordinance or individual district contracts, a BID is a model of sublocal governance, a geographic subdivision within a municipality, which provides district-limited services to supplement those already provided by local government. ${ }^{12}$ BID formation statutes generally require that local government and property owners both approve the district. ${ }^{113}$ BIDs are usually managed by a public or private BID board that advises, or is advised by, local government officials. ${ }^{114}$ By one count, thirteen percent of BIDs are operated by public agencies, twenty-six percent by mixed public nonprofit partnerships, and sixty-one percent by not-for-profit organizations. ${ }^{115}$ BIDs are financed primarily by assessments on local property, given their highly regulated power to tax the property owners in the district, but otherwise they have no governmental powers. The CEC enabling statute, like the typical BID statute, would require the CEC charter to state the boundaries, affect properties, and basic operating and financing structure of a CEC. CECs will need technical assistance to make informed judgments about the development proposal on which they will vote, and this essential cost should be provided for expressly in the enabling legislation. States with affordable housing trust (AHT) funds, or with local jurisdictions having municipal AHTs, may specify CECs as a categorical recipient entitled to apply for such funds as well. ${ }^{116}$

\footnotetext{
${ }^{112}$ Richard Briffault, A Government for Our Time? Business Improvement Districts and Urban Governances, 99 COLUM. L. REV. 365, (1999)

${ }^{113}$ See, e.g., Ind. Code Ann. § 36-9-38-8 (West, WESTLAW through 2002 1st Spec. Sess.) (allowing formation process to begin with approval of owners of twenty percent of affected property).

${ }_{114}$ BID enabling statutes generally require that district plans include boundaries, planned expenditures, and other components of the basic operating and financial structure of a BID. E.g., N.Y. Gen. Mun. Law § 980-a (McKinney, WESTLAW through 2002 legislation).

${ }^{115}$ BIDs Fare Well, 78 N.Y.U. L. REV. 374, 374 n.1 (2003) (citing Mitchell study).

${ }^{116}$ ROM study underscores the importance of technical assistance for success.
} 
The enabling legislation would also define the length and character of tenures entitling residents to Homestead Stakes; and the contents for, or model of, charter documents for the CEC.

This legislation would enable the community residents to engage in collective action, through a collective voting mechanism, to approve or disapprove the conveyance of their neighborhood to the city or its development designee seeking to assemble the communityoccupied land. Formation of the CEC at the relevant time in the development deal-making would equip the community to bargain based on the consolidated value of the many parcels to the other players in the deal-making. Municipal facilitation of CECs is an appropriate correction to the civic, social, and economic inequities that public/private development deal-making practices externalize onto low-wealth communities. The combined interests proposed here, of Community Equity Corporations facilitated by city government, and Community Equity Shares in the redevelopment when the community does indeed agree to acquisition, together require the redevelopment to internalize more of the true social costs it will produce.

\section{CONCLUSION: ADAPTING OWNERSHIP SPREADING TO COMMUNITY REDEVELOPMENT PRACTICE}

The provenance for the Community Equity Shares concept derives from the policies of equitable development and social inclusion that undergird federal community development law since the 1960s. A "Community Interest Corporation" demonstration program was introduced in the Housing and Urban Rural Recovery Act of 1983; then reconfigured as "community investment corporations" in federal housing legislation of 1992, with the purpose to replicate successful community capital initiatives like South Shore Bank in Chicago and Community Self- 
Help in Durham, North Carolina. The federal program promoted depository institutions ${ }^{117}$ with the mission to revitalize a geographic area. Each local institution would be statutorily obligated to maintain "accountability to community residents" through "significant representation on its governing board and otherwise."

The issuance of equity shares also seeks to address inequities that are the aim of several models of public contracting. For example, state and local procurement statutes commonly condition the selection of private developers upon contractual commitments to work with a designated community representative. Procurement rules make engagement of the targeted community residents - through a representative at the decision table - a ranked criterion in requests for proposals, development agreements and regulatory agreements; and incorporated into the legal documentation of each partnership deal. Such conditions are frequently imposed ad hoc in many jurisdictions, thus legislating the practice would be the reasonable next step. Many states allow certain public contracts to be awarded based on "best value," a concept which is evolving beyond traditional concerns for low price and responsible bidder to allow public contracting agencies to consider additional factors, ${ }^{118}$ including "negotiated procurement" and “deal local" provisions. ${ }^{119}$

Retooling the legal regime for urban redevelopment for the inclusionary operation of familiar capital orchestration draws upon predicates in our legal history for transforming

\footnotetext{
${ }^{117}$ Or nonprofit affiliates of nondepository lending institutions or regulated financial institutions.

${ }^{118}$ Dean B. Thomson \& Michael J. Kinzer, Best Value in State Construction Contracting, 19 CONSTRUCTION LAW., Apr. 1999, at 31. States' best value procurement rules are variously named "innovative procurement," "negotiated procurement," "performance-based procurement," and "competitive negotiation." Id. at 32 (quotations and citations omitted). In fact, some states specifically exclude cost as a consideration in the initial stage of the procurement's "best value" standard. Id.

119 A procurement rule requiring bidders to "deal local" is in some sense analogous to the familiar example of "Buy America" and "Buy In-State" preferences, which many states have enacted in their design-build procurement laws. See id. (noting that in some jurisdictions locality of the vendor should be a factor in the best value equation).
} 
associational and democratic participation into ownership-spreading equity-like participations.

Examples in real estate contexts include financial institutions with resident ownership (community development credit unions) ${ }^{120}$ multiple forms of home-equity cooperative ventures; ${ }^{121}$ a long history of agricultural cooperatives ${ }^{122}$ as well as producer and consumer cooperatives; ${ }^{123}$ employee ownership in the forms of Employee Stock Ownership Plans ("ESOPs") ${ }^{124}$ and worker owned cooperatives; ${ }^{125}$ public mechanisms to support resident investment such as IRAs and IDAs; ${ }^{126}$ and state recognition of the shared-holding aspect of citizens in an exhaustible natural resource. ${ }^{127}$

U.S. policy has been extremely successful in ownership-spreading with the important and

${ }^{120}$ See, e.g., National Federation of Community Development Credit Unions-About Us, http://www.natfed.org/i4a/pages/index.cfm?pageid=256 (last visited Oct. 19, 2006) (describing the history and purpose of Community Development Credit Unions).

121 See 42 U.S.C. $\$ 12773$ (f) (2000) (defining community land trusts); see generally Duncan Kennedy, The Limited Equity Coop as a Vehicle for Affordable Housing in a Race and Class Divided Society, 46 How. L.J. 85 (2002) (discussing the limited equity housing co-op as an alternative form of property and comparing it to the leasing cooperative and community land trust).

${ }_{122}$ See Thomas Broden, Note, Co-operatives-A Privileged Restraint of Trade, 23 NOTRE DAME LAW. 110, 114-19 (1947) (describing the history of agricultural cooperatives).

${ }^{123}$ See JosepH G. KNAPP, ThE RISE OF AMERICAN COOPERATIVE ENTERPRISE: 1620-1920, at 418-30 (1969) (discussing the spread of the cooperative from agriculture into other areas, including telephone service, mutual insurance, and mutual savings banks).

${ }^{124}$ In an ESOP, a company sets up a trust fund, into which it contributes new shares of its own stock or cash to buy existing shares. Alternatively, the ESOP can borrow money to buy... shares. National Center for Employee Ownership, How an Employee Stock Option Plan (ESOP) Works, http://www.nceo.org/library/esops.html, (last visited Oct. 16, 2006). The ESOP can make tax deductible contributions to the plan with which to repay the loan. "Shares in the trust are allocated to individual employee accounts." Id. Plans specify the employee categories that participate in the plan, and the formula for the allocations. "In private companies, employees must be able to vote their allocated shares on major issues, such as closing or relocating [the company]," and the company can accord voting rights on additional issues (including the board of directors). Id. About 10,000 companies now have employee stock ownership plans, up from 200 in 1974. Crystal Detamore-Rodman, Branching Out: An Employee Stock Ownership Plan is More than Just a Great Way to Boost Morale, 32 ENTREPRENEUR, Apr. 1, 2004, at 61.

125 See Louis O. Kelso \& PATRICIA HetTER, How to TURN EIGHTY MILliON WorkERS INTO CAPITALISTS ON Borrowed Money 84 (1967); Louis O. Kelso \& PATRICIA HeTter Kelso, DemOCRACY AND ECONOMIC POWER: EXTENDING THE ESOP REVOLUTION 52 (1986); see also Hockett, supra note_59, at 102-04; Peter Pitegoff, Child Care Enterprise, Community Development, and Work, 81 GEO. L.J. 1897, 1897 (1993) (proposing the use of "[c]hild care enterprise [as] a vehicle for community-based economic development").

12642 U.S.C. \$ 604(h) (2000) (defining individual development accounts); see also Creola Johnson, Welfare Reform and Asset Accumulation: First We Need a Bed and a Car, 2000 WIS. L. REV. 1221 (discussing theoretical framework of individual development accounts and their availability, usage, and success).

127 Alaska's Permanent Fund Dividend Program pays each qualified resident of the state an annual dividend from the Alaska Permanent Fund. AlaskA ADMIN. CoDE tit. 15, § 23.103-23 (2006). The Fund, created by the state constitution in 1977, invests one quarter of all revenue the state receives from the sale or rental of its mineral resources. ALASKA CONST. art. IX, $\S 15$. Since 1982, when the current version of the program was enacted, the dividends have averaged more than \$1000. See Alaska Permanent Fund Corp., The Permanent Fund Dividend, http://www.apfc.org/alaska/dividendprgrm.cfm (last visited Oct. 19, 2006). 
enduring success of the federal home finance structure developed through the 1930s and 1940s. ${ }^{128}$ That innovation has been paralleled in the case of "human capital" spreading through: public provision of primary and secondary education; the land grant acts of the nineteenth century by which federal land "staked" the perpetual endowments for state colleges and universities; the G.I. Bill following World War II that united in one program both loan guarantees and education as an asset; and direct and indirect loans, grants, and subsidies for higher education. $^{129}$

The Community Equity Corporation proposed here is premised on connecting the citizenry of a geographic place to the economic generative opportunities of that place. It corresponds to the general stock ownership corporation ("GSOC") envisioned by Louis Kelso, the inventor of the now widely used employee stock ownership plan. ${ }^{130}$ The Kelsonian GSOC was designed to be a highly adaptable device to "ownerize" on a regional or community based scale, for example to create community-wide ownership of local business. ${ }^{131}$

Community equity shareholding allows residents in the path of public/private redevelopment the opportunity to enjoy not just benefit, but also ownership in the enterprise. The voting right attached to the resident share provides a basis for collective bargaining over the character of the development, and in this way may mirror CBAs' utility for community collaborators to wrest detailed provisions for affordable housing, local hiring, job training, and amenities such as parks

128 Hockett, supra note 59, at 104-17.

129 Id. at 143-53.

130 See JefF GATES, The OWNERShip SOlution: TOWARd A SHAREd CAPITALISM FOR THE TWENTY-FIRST CENTURY 20 (1998).

131 Id. at 55-58 (1998). Gates suggests that municipalities that use buy-lease arrangements to finance large land acquisitions could readily restructure such acquisitions as GSOCs to achieve broadly diversified individual ownership by community residents. Likewise, metropolitan area transit authorities that lease commercial space associated with their rail stations could restructure these dealings as Community Equity Corporations and achieve shared ownership by community residents. $I d$. at 76-77. Revenue Act of 1978, Pub. L. No. 95-600, 92 Stat. 2762, 2893 (1978) (adding subchapter U to the Internal Revenue Code); see GATES, supra note 137, at 76. 
and school investments. Market Creek Plaza's community resident investors demonstrate that residents can successfully co-exist and co-own thriving commercial ventures. The Community Equity Shareholding proposal suggests a means for localities to meld the two in intentionally inclusionary and equity-sharing public/private redevelopments, whose neighborhood effects will induce tremendous changes to the face, and heart, of the community. 